\title{
A Comprehensive Study of the Anatomical Variations of the Posterolateral Tubercle of Talus
}

\author{
Un Estudio Integral de las Variaciones Anatómicas del Tubérculo Posterolateral del Talo
}

\author{
Heba Kalbouneh ${ }^{1}$; Mohammad Alsalem'; Maysoon Bani Hani' ${ }^{2}$;amzeh Alhusamiah²; \\ Yazan Momani ${ }^{1}$; Talal Massad ${ }^{1}$; Tamer Barakat ${ }^{1}$ \& Omar Alajoulin $^{3}$
}

KAlbOUNEH, H.; AlSAlEM, M.; BANI HANI, M.; AlHUSAMIAH, H.; MOMANI, Y.; MASSAD, T.; BARAKAT, T. \& ALAJOULIN, O. A comprehensive study of the anatomical variations of the posterolateral tubercle of talus. Int. J. Morphol., 39(3):858863, 2021.

SUMMARY: The aim of our study was to determine the prevalence and the anatomical variations of the posterolateral tubercle of talus in relation to sex on CT imaging. A total of 1478 ankle CT scans was retrospectively reviewed for the different anatomical variants of the posterolateral tubercle of talus, the type and size of os trigonum. Normal sized lateral tubercle was found in $46.1 \%$, an enlarged posterolateral tubercle (Stieda's process) in $26.1 \%$, os trigonum in $20.5 \%$ and almost absent tubercle in $7.3 \%$. A statistically higher prevalence of Stieda's process was found in males while os trigonum was higher in females $(\mathrm{p}<0.05)$. Among feet with os trigonum, $25.7 \%$ were non-articulating and identified as a separate bone located posterior to the posterolateral tubercle of talus and 74.3 $\%$ of os trigonum were identified as fused to the posterolateral tubercle by synchondrosis or syndesmosis. Additionally, $17.5 \%$ of os trigonum were associated with intact lateral tubercle, $53.5 \%$ were considered as part of the lateral tubercle and $29.0 \%$ were without a lateral tubercle. According to its size, $22.8 \%$ of os trigonum were smaller than $0.5 \mathrm{~cm}, 55.4 \%$ were between 0.5 and $1 \mathrm{~cm}$, and $21.8 \%$ were larger than $1 \mathrm{~cm}$. No significant differences were found between the different types/sizes of os trigonum according to gender $(\mathrm{p}>0.05)$. The posterolateral tubercle of talus and its accessory ossicle, the os trigonum, could vary morphologically. The data of this study could be helpful in understanding the clinical problems that could be associated with some of these variants.

KEY WORDS: Os trigonum; Stieda's process; Talus; Prevalence; Morphology; Posterior ankle impingement

\section{INTRODUCTION}

The posterior process of the talus is made up of two tubercles, the medial tubercle and the lateral tubercle. Between these tubercles is a groove that allows the passage of the flexor hallucis longus tendon from the posterior ankle to enter the tarsal tunnel (Drake et al., 2015). The lateral tubercle is generally larger and serves as an attachment point for the posterior talofibular ligament and the posterior talocalcaneal ligament (Sarrafian \& Kelikian, 2011). An accessory bone, the os trigonum can occur in continuity with the lateral tubercle of talus. It begins to appear between the ages of 8-11 years in boys and 8-10 years in girls as a secondary center of ossification for the posterior process of talus. Normally it fuses with talus within a year (Eastwood, 2002). If the ossicle fails to fuse, it is referred to as the os trigonum. Fusion results in the formation of a prominent lateral tubercle of the posterior talus, termed as a Stieda's process.
A wide variation in the size of the lateral tubercle of talus and the os trigonum is present. Sarrafian \& Kelikian classified the lateral tubercle of talus according to its size into: absent, moderate, medium and large. Medium and large lateral tubercles were identified in the study of Zwiers et al. (2018) as an enlarged Stieda's process. For the variations of os trigonum, it can be fused with the lateral tubercle by a cartilaginous or fibrous articulation or be a separate fragment not articulating with the posterior talus (Howse, 1982; Mann \& Owsley, 1990; Murphy, 2003).

Watson \& Dobas (1976) described a classification scheme for the anatomical variations of the posterolateral tubercle of talus. Type 1 was identified as a normal appearance of the lateral tubercle without clinical consequence. Type 2 is the Stieda's process (an enlarged posterolateral process). Type 3 is the os trigonum, which

\footnotetext{
${ }^{1}$ Department of Anatomy, Faculty of Medicine, University of Jordan, Amman, Jordan.

${ }^{2}$ Radiology Department, Jordanian Royal Medical Services, Jordan.

${ }^{3}$ Orthopedic and Trauma Department-Ankle and Foot Section, Jordanian Royal Medical Services, Jordan.
} 
may be the source of discomfort because of repetitive trauma. Type 4 is a fused os trigonum, which forms a synchondrosis or syndesmosis with the talus.

There is a paucity of work upon the prevalence of the four anatomical variations of the posterolateral tuberclein a single comprehensive study. However, the frequency of occurrence of the os trigonum alone was widely investigated in normal feet and it varies from 2 to $50 \%$ (Burman \& Lapidus, 1931; Mann \& Owsley), and a population- specific incidence was also reported for os trigonum (Mann \& Owsley; Zwiers et al.). On the other hand, the frequency of the enlarged posterolateral talar tubercle (Stieda's process) is rarely reported with incidences of $35.7 \%$ and $14.7 \%$ in the Netherlands and Chinese population, respectively (Zwiers et al.; Fu et al., 2019). The aim of this study was to provide a comprehensive understanding of the anatomical variations of the posterolateral tubercle of talus and to establish their prevalence on CT imaging.

\section{MATERIAL AND METHOD}

Ankle CT scans of adolescent and adult patients made between March 2018 and March 2020 were retrospectively reviewed for the different anatomical variants of the posterolateral tubercle of talus and its accessory bone, the os trigonum.

Excluded from the study were patients aged less than 14 years, patients with ankle fracture, instability, avulsion fractures of the tibia, fibula, or lateral tubercle of talus (Shepherd fracture), patients who underwent hindfoot surgery, patients with pathologies including osteolysis, severe arthritis, osteochondritis dissecans, avascular necrosis, and congenital deformations of the ankle joint. This study was approved by the Academic Research Council and the Ethics Committee. Age and sex data were obtained from hospital medical records.

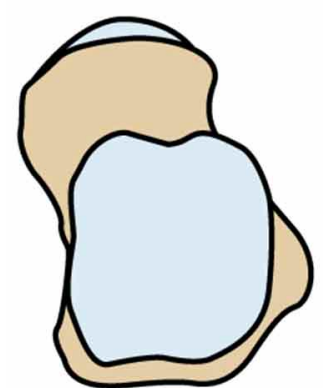

Type 1

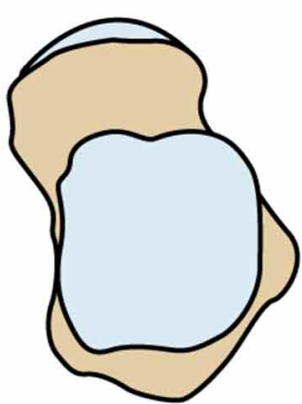

Type 2

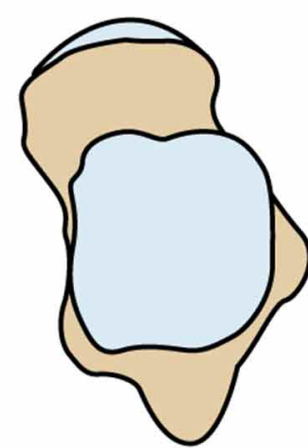

Type 3

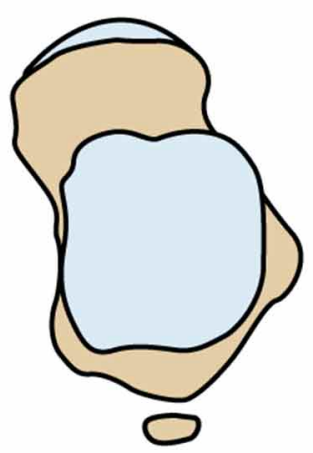

Type 4
Fig. 1. Variations in the posterolateral tubercle of talus. 1: Almost absent, 2: Normal, 3: Enlarged (Stieda's process), and 4: Os trigonum. 

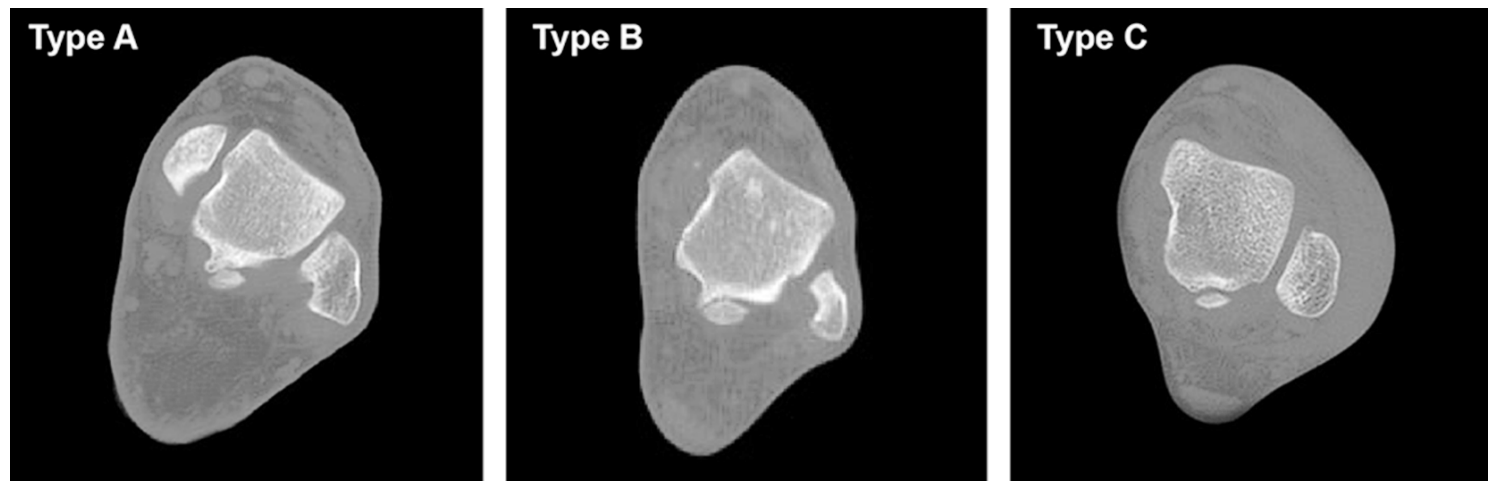

Fig. 2. Axial multiplanar reformatted images of ankle computed tomography showing different types of os trigonum according to Zwier et al classification (Zwiers et al., 2018): Type A: os trigonum with intact posterolateral tubercle, Type B: os trigonum as part of the posterolateral tubercle and Type C: os trigonum without posterolateral tubercle.

Using a sample of $50 \mathrm{CT}$ scans, inter-rater reliability was analyzed using the Cohen's Kappa to assess the consistency between the two investigators. A third investigator was consulted in case of disagreement in identifying different variants of the posterolateral tubercle and the type of os trigonum. The significance threshold was set at the value of $\mathrm{p} \leq .05$.

\section{RESULTS}

The average age was 33.7 (range, 14-63) years. Of the patients, $58.2 \%$ were males. The prevalence of different anatomical variants of the posterolateral tubercle was identified as: almost absent (7.3\%), normal tubercle (46.1 $\%)$, Stieda's process $(26.1 \%)$, and os trigonum $(20.5 \%)$. The prevalence of Stieda's process was statistically higher in males while os trigonum was statistically higher in females $(\mathrm{p}<0.05)$. No significant difference was found between sides (Table I).

Prevalence of type and size of os trigonum was shown in Table II. Among 303 feet with os trigonum, $25.7 \%$ (78/ $303)$ were identified as Type 1 and $74.3 \%$ (225/303) were identified as Type 2. Additionally, Type A was identified in $17.5 \%$ (53/303), Type B in $53.5 \%$ (162/303) and Type C in $29.0 \%$ (88/303) (Fig. 2). No significant difference was found between the two types of os trigonum according to sex (p>0.05) (Table II).

Regarding the size of os trigonum, $22.8 \%(69 / 303)$ was smaller than $0.5 \mathrm{~cm}, 55.4 \%$ (168/303) was between 0.5 and $1 \mathrm{~cm}$, and $21.8 \%(66 / 303)$ was larger than $1 \mathrm{~cm}$. No significant difference was found between the different sizes of os trigonum according to sex (p>0.05) (Table II).
Inter-rater agreement (Kappa statistics) over identification of the different anatomical variants of the posterolateral tubercle (except for Stieda's process) and types of os trigonum was perfect (kappa > 0.9). Inter-rater agreement for defining an enlarged Stieda's process was substantial with a kappa of 0.79 .

\section{DISCUSSION}

In our study, we examined the prevalence of different anatomical variants of the posterolateral tubercle of talus using CT scans. In the $1478 \mathrm{CT}$ scans examined, the most common variant was the normal sized tubercle $(46.1 \%)$, followed by Stieda's process ( $26.1 \%$ ), and os trigonum (20.5 $\%)$. An almost absent tubercle was the least common variant $(7.3 \%)$. A higher prevalence of Stieda's process was found in males while os trigonum was higher in females suggesting that bony union with the posterior talus is more likely to occur in males.

There is a wide variation in the reported incidence of the os trigonum in previous studies. The lowest incidence reported in the literature was $1.7 \%$ (Mann \& Owsley). On the other hand, the highest incidence was reported by Burman \& Lapidus. They studied 1000 feet X-rays and reported a high occurrence of $50 \%$ but only $6 \%$ of them were truly separated. In the study of Zwiers et al., using 1256 foot and ankle CTs, the presence of os trigonum, size and type were assessed, and a high incidence of $32.5 \%$ was reported. In addition, the most common type of os trigonum in their study was type B (50.3\%-46.8\%), where the os trigonum was identified as part of the posterolateral tubercle, and $57 \%$ of the os trigonum was between 0.5 and $1.5 \mathrm{~cm}$. These findings are comparable to our results (Table II). However, we studied 
Table I. The anatomical variations of the posterolateral tubercle of talus According to sex and side.

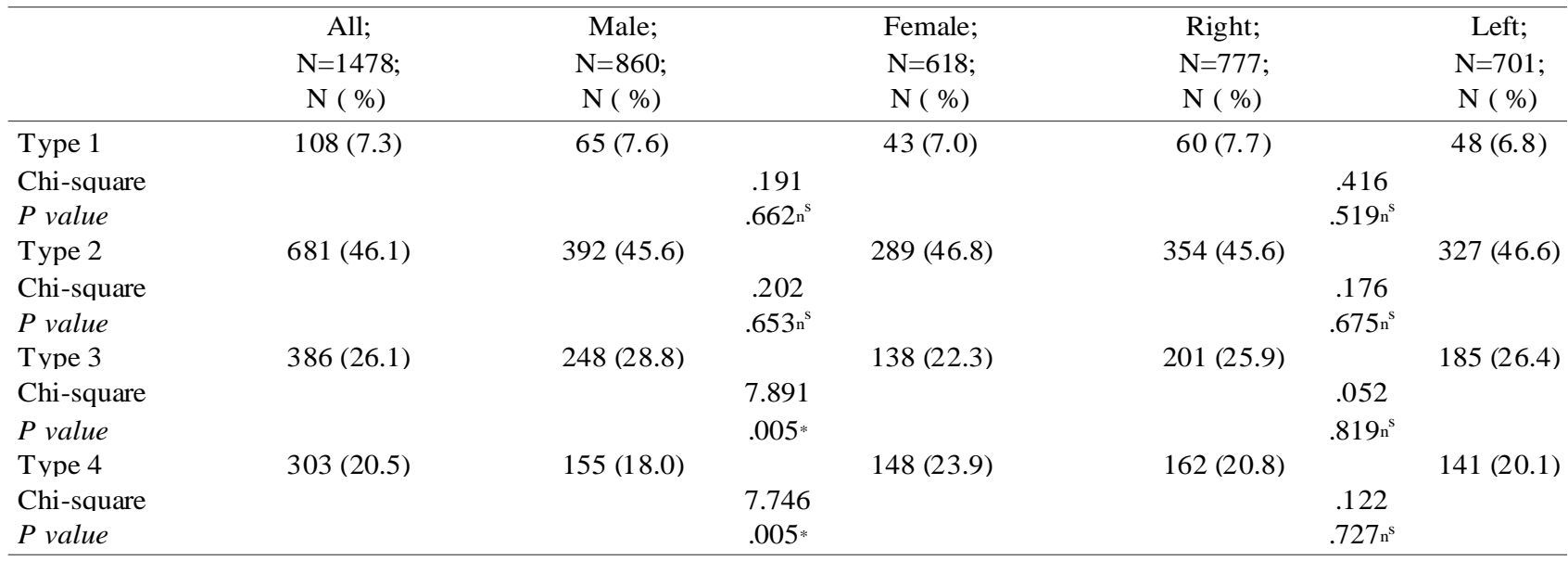

* significant, ${ }^{\mathrm{ns}}$ not significant.

Table II. Prevalence of type and size of os trigonumaccording to sex.

\begin{tabular}{|c|c|c|c|}
\hline & $\begin{array}{c}\text { All } \\
\mathrm{N}=303 \\
\mathrm{~N}(\%)\end{array}$ & $\begin{array}{c}\text { Male } \\
\mathrm{N}=153 \\
\mathrm{~N}(\%)\end{array}$ & $\begin{array}{l}\text { Female } \\
\mathrm{N}=150 \\
\mathrm{~N}(\%)\end{array}$ \\
\hline \multicolumn{4}{|l|}{ Type of os trigonum } \\
\hline Type 1 & $78(25.7)$ & $43(28.1)$ & $35(23.3)$ \\
\hline Type 2 & $225(74.3)$ & $110(71.9)$ & $115(76.7)$ \\
\hline Chi-square & & \multicolumn{2}{|c|}{.902} \\
\hline$P$ value & & \multicolumn{2}{|c|}{$.342^{\mathrm{ns}}$} \\
\hline Type A & $53(17.5)$ & $28(18.3)$ & $25(16.7)$ \\
\hline Type B & $162(53.5)$ & $87(56.9)$ & $75(50.0)$ \\
\hline Type C & $88(29.0)$ & $38(24.8)$ & $50(33.3)$ \\
\hline Chi-square & & \multicolumn{2}{|c|}{2.666} \\
\hline$P$ value & & \multicolumn{2}{|c|}{$.264^{\mathrm{ns}}$} \\
\hline \multicolumn{4}{|l|}{ Size of os trigonum } \\
\hline Smaller than $0.5 \mathrm{~cm}$ & $69(22.8)$ & $37(24.0)$ & $32(21.5)$ \\
\hline Between 0.5 and $1 \mathrm{~cm}$ & $168(55.4)$ & $81(52.6)$ & $87(58.4)$ \\
\hline Larger than $1 \mathrm{~cm}$ & $66(21.8)$ & $36(23.4)$ & $30(20.1)$ \\
\hline Chi-square & & \multicolumn{2}{|c|}{1.040} \\
\hline$P$ value & & \multicolumn{2}{|c|}{$.595^{\mathrm{ns}}$} \\
\hline \multicolumn{4}{|c|}{${ }^{*}$ significant, ${ }^{\text {ns }}$ not significant. } \\
\hline
\end{tabular}

the prevalence of different anatomical types and sizes of os trigonum according to sex and no significant differences were found. A population- specific incidence was also reported for os trigonum. Os trigonum was not found in a cohort of Native Americans and Inuits (Mann \& Owsley). Additionally, in the study of Zwiers et al., performed in the Netherlands, eight different ethnicity groups classified according to the country of birth or the country of birth of the patient's parents were included. Afro-Caribbean/ Surinamese/Central African origin was associated with a lower rate of occurrence of an os trigonum. In our previous work, the incidence of os trigonum in non-athletic patients with sprained ankles was assessed. The incidence of os trigonum was $20.4 \%$ of sprained ankles, with a higher incidence in females (Kalbouneh et al., 2019).

The different morphological variants of os trigonum described in this study were also previously identified in a CT based study of a Chinese population (Fu et al.). Three basic types of os trigonum based on the mode of connection were identified; Type 1 was a single bone that was not connected to talus, type 2 was connected to the posterior 
talar process by a hyaline cartilage, and type 3 was the Stieda's process. Similar to our results, Stieda's process was more common than os trigonum, and the connected form of os trigonum is more common than the separate form.

Little knowledge on the exact occurrence of Stieda's process is available. This may be attributed to the lack of a standard definition for the enlarged posterolateral tubercle. In the study of Zwier et al., Stieda's process was found in about one-third of the patients without os trigonum (Zwiers et al.). In another CT based study of a Chinese population, Stieda's process was identified in $14.7 \%$ of patients ( $\mathrm{Fu}$ et al.).

An understanding of the anatomy is fundamental for recognizing the occurrence of the related diseases that could be caused by the different anatomical variants. Posterior ankle impingement (PAIS) is a condition characterized by posterior ankle pain in plantar flexion. It is usually aggravated by repetitive plantar flexion and can result from either an acute injury or simple overuse (Russell et al., 2010; Sofka, 2010; Ribbans et al., 2015). Eighty- one percent of the pathologies causing PAIS were reported to be osseous in origin and os trigonum accounted for $47 \%$ of these cases while Stieda's process accounted for only $4 \%$ (Ribbans et al.). Zwiers et al. reported a higher prevalence (46.4\%) of os trigonum in patients with posterior impingement complaints using CT images. In a recent study evaluating the prevalence of os trigonum using ankle MRI, os trigonum was found in $63.3 \%$ in patients with PAIS (Ozer \& Yildirim, 2019).

In our study, most of os trigonum were of a fused type $(74.3 \%)$. The fused type of os trigonum could be at higher risk for developing symptoms compared to a separate ossicle. Usually the os trigonum is asymptomatic; however, symptoms such as pain and swelling can occur particularly during sporting activities requiring repetitive forced plantar flexion of the foot (Ribbans et al.; Kudas, et al., 2016). Repetitive plantar flexion/dorsiflexion may result in degeneration or tear of the synchondrosis posing the fused type of os trigonum at higher risk for developing symptoms. The anatomical variations of os trigonum should be taken into consideration in our population especially in patients with posterior impingement complaints. The repetitive plantarflexion/dorsiflexion is a continuous requirement during Muslim prayer which may cause disruption of the synchondrosis between the os and the talus or causing compression of the ossicle/ Stieda's process against the tibia (Kalbouneh et al.). Further studies are recommended to assess the prevalence of different anatomical variants of the posterolateral tubercle of talus in patients diagnosed clinically and radiologically with PAIS, and to evaluate the risk posed by different anatomical variants to PAIS
In conclusion, the anatomy of the posterolateral tubercle of talus is variable. An understanding of this anatomy is fundamental for recognizing the occurrence of the different symptoms that could be associated with them. Orthopedic surgeons should be aware of these variations during ankle arthroscopic procedures.

KALBOUNEH, H.; ALSALEM, M.; BANI HANI, M.; ALHUSAMIAH, H.; MOMANI, Y.; MASSAD, T.; BARAKAT, T. \& ALAJOULIN, O. Un estudio integral de las variaciones anatómicas del tubérculo posterolateral del talo. Int. J. Morphol., 39 (3):858-863, 2021.

RESUMEN: El objetivo de nuestro estudio fue determinar la prevalencia y las variaciones anatómicas del tubérculo posterolateral del talo en relación con el sexo en la imagen de TC. Se revisaron retrospectivamente un total de 1478 TC de tobillo para las diferentes variantes anatómicas del tubérculo posterolateral del talo, el tipo y tamaño del os trigonum. Se encontró tubérculo lateral de tamaño normal en 46,1\%, tubérculo posterolateral (proceso de Stieda) en 26,1\%, os trigonum en 20,5 $\%$ y tubérculo casi ausente en $7,3 \%$. Se encontró una prevalencia estadísticamente más alta del proceso de Stieda en los hombres, mientras que el os trigonum fue mayor en las mujeres ( $\mathrm{p}<0,05$ ). Entre los pies con os trigonum, el 25,7\% no se articulaban y se identificaba como un hueso separado ubicado posterior al tubérculo posterolateral del talo y el 74,3\% del os trigonum se identificaba como fusionado con el tubérculo posterolateral por sincondrosis o sindesmosis. Además, el 17,5\% del os trigonum se asoció con tubérculo lateral intacto, el 53,5\% fue considerado como parte del tubérculo lateral y el 29,0\% sin tubérculo lateral. Según su tamaño, el 22,8 \% de los os trigonum eran menores de $0,5 \mathrm{~cm}$, el $55,4 \%$ tenían entre 0,5 y $1 \mathrm{~cm}$ y el $21,8 \%$ eran mayores de $1 \mathrm{~cm}$. Entre los diferentes tipos / tamaños de os trigonum según el sexo $(p>0,05)$ no se observaron diferencias significativas. El tubérculo posterolateral del talo y su osículo accesorio, el os trigonum, podrían originar problemas clínicos que podrían estar asociados con algunas de estas variantes.

PALABRAS CLAVE: Os trigonum; El proceso de Stieda; Talo; Predominio; Morfología; Pinzamiento posterior del tobillo.

\section{REFERENCES}

Burman, M. \& Lapidus, P. The functional disturbances caused by the inconstant bones and sesamoids of the foot. Arch. Surg., 22(6):936-75, 1931.

Drake, R. L.; Vogl, A. W. \& Mitchel, A. W. Gray's Anatomy for Students. 3rd ed. Philadelphia, Elsevier, 2015.

Eastwood, D. Foot Injuries in Children. Pediatric trauma. In: Bulstrode, C.; Buckwalter, J.; Carr, A.; Marsh, L.; Fairbank, J.; MacDonald, J. W. \& Bowden, G. (Eds.). Oxford Textbook of Orthopedics and Trauma. Vol. 3. New York, Oxford University Press, 2002. pp.2743-50. 
Fu, X.; Ma, L.; Zeng, Y.; He, Q.; Yu, F.; Ren, L.; Luo, B.; Fu, S. \& Zhang, L. Implications of classification of os trigonum: a study based on computed tomography three-dimensional imaging. Med. Sci. Monit., 25:1423-8, 2019.

Howse, A. J. Posterior block of the ankle joint in dancers. Foot Ankle, $3(2): 81-4,1982$.

Kalbouneh, H. M.; Alajoulin, O.; Alsalem, M.; Mansour, Y.; Shawaqfeh, J.; Altarawneh, T.; Alhusni, D. \& Al-Muhtaseb, M. H. Incidence of symptomatic os trigonum among nonathletic patients with ankle sprain. Surg. Radiol. Anat., 41(12):1433-9, 2019.

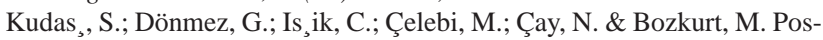
terior ankle impingement syndrome in football players: Case series of 26 elite athletes. Acta Orthop. Traumatol. Turc., 50(6):649-54, 2016.

Mann, R. W. \& Owsley, D. W. Os trigonum. Variation of a common accessory ossicle of the talus. J. Am. Podiatr. Med. Assoc., 80(10):5369, 1990.

Murphy, G. A. The Foot and Ankle. Fractures and Dislocations Of Foot. In Canale, S. T. (Ed.). Campbell's Operative Orthopaedics. 10th ed. Philadelphia, Mosby, 2003. pp.4257.

Ozer, M. \& Yildirim, A. Evaluation of the prevalence of os trigonum and talus osteochondral lesions in ankle magnetic resonance imaging of patients with ankle impingement syndrome. J. Foot Ankle Surg., 58(2):273-7, 2019.

Ribbans, W. J.; Ribbans, H. A.; Cruickshank, J. A. \& Wood, E. V. The management of posterior ankle impingement syndrome in sport: a review. Foot Ankle Surg., 21(1):1-10, 2015.

Russell, J. A.; Kruse, D. W.; Koutedakis, Y.; McEwan, I. M. \& Wyon, M. A. Pathoanatomy of posterior ankle impingement in ballet dancers. Clin. Anat., 23(6):613-21, 2010.

Sarrafian, S. K. \& Kelikian, A. S. Osteology. In: Kelikian, A. S. (Ed.). Sarrafian's Anatomy of the Foot and Ankle. Descriptive, Topographic, Functional. 3rd ed. Philadelphia, Lippincott, 2011. pp.40-199.

Sofka, C. M. Posterior ankle impingement: clarification and confirmation of the pathoanatomy. HSS J., 6(1):99-101, 2010.

Watson C.A. \& Dobas D.C. The os trigonum: a discussion and case report. Arch. Podiatr. Med. Surg., 3:17, 1976.

Zwiers, R.; Baltes, T. P. A.; Opdam, K. T. M.; Wiegerinck, J. I. \& van Dijk, C. N. Prevalence of os trigonum on CT imaging. Foot Ankle Int., 39(3):338-42, 2018.

\author{
Corresponding author: \\ Heba M. Kalbouneh \\ Associate Professor \\ Department of Anatomy and Histology \\ Faculty of Medicine \\ University of Jordan \\ Amman 11942 \\ JORDAN
}

Orcid: 0000-0002-0956-9223

E-Mail: heba.kalbouneh@ju.edu.jo

Received: 12-01-2021

Accepted: 04-04-2021 